Journal of Applied Biology \& Biotechnology Vol. 5 (01), pp. 076-078, Jan-Feb, 2017

Available online at http://www.jabonline.in

DOI: $10.7324 / \mathrm{JABB} .2017 .50113$

(c) $\mathrm{BY}-\mathrm{NC}-\mathrm{SA}$

\title{
Effect of Artificially Induced Drought Stress on Seedlings of Pinus roxburghii Sarg
}

\author{
Ashish Tewari*, Amit Mittal \\ Department of Forestry and Environmental Science, Kumaun University, Nainital-263001, India.
}

\begin{tabular}{|c|c|}
\hline ARTICLE INFO & ABSTRACT \\
\hline $\begin{array}{l}\text { Article history: } \\
\text { Received on: } 04 / 10 / 2016 \\
\text { Revised on: } 05 / 11 / 2016 \\
\text { Accepted on: } 25 / 11 / 2016 \\
\text { Available online: } 20 / 01 / 2017\end{array}$ & $\begin{array}{l}\text { Water relation and growth parameters of drought stressed seedlings of Chir pine (Pinus roxburghii Sarg.) were } \\
\text { studied over a one year period. The seedlings were subjected to three drought cycles of } 9,18,27 \text { days and one } \\
\text { control level (watered every alternate day) in a polyhouse. Pre-dawn (5.30-6.30 AM) and Mid-day water potential } \\
\text { was estimated using a pressure chamber. The bench drying method was followed for developing P-V curves for } \\
\text { estimating components of water potential. Osmotic adjustment was estimated as the difference between the }\end{array}$ \\
\hline $\begin{array}{l}\text { Key words: } \\
\text { Osmotic adjustment; Water } \\
\text { potential; Pinus roxburghii; } \\
\text { Moisture stress. }\end{array}$ & $\begin{array}{l}\text { osmotic potential at zero and full turgor of seedlings kept at control and those given } 27 \text { days drought. Across } \\
\text { drought cycles the pre- dawn water potential ranged between }-0.59 \mathrm{MPa} \text { and }-2.12 \mathrm{MPa} \text { and the mid-day water } \\
\text { potentials were always lower than pre-dawn water potentials. The Osmotic adjustment was }-1.17 \mathrm{MPa} \text { at full } \\
\text { turgor and }-2.0 \mathrm{MPa} \text { at zero turgor. The seedlings growth was positively related to soil moisture and water } \\
\text { potential. The daily change in water potential (difference between pre-dawn and mid-day water potential) declined } \\
\text { with increasing drought and was nominal (less than }-0.2 \mathrm{MPa} \text { ) in seedlings subjected to } 18 \text { and } 27 \text { days drought } \\
\text { cycle. Needle characteristics were severely affected by water stress. In Pinus roxburghii Sarg seedlings osmotic } \\
\text { adjustment may be an important adaptive mechanism that assists it to invade and grow on dry inhospitable sites. }\end{array}$ \\
\hline
\end{tabular}

\section{INTRODUCTION}

The survival of tree species depends on their capacity to tolerate drought particularly in tropical ecosystem [1]. Trees can tolerate stress for water by maximizing uptake or reducing water loss [2]. A modification in physiological characteristics is another mechanism to overcome drought in most tree species. Due to small size and limited root depth the seedlings are least tolerant to harsh environment [3]. Himalayan forests face 5-6 months of drought every year as they are governed by monsoonal pattern of rainfall [4]. Leaf life span of most evergreen tree species is close to one year in central Himalayan region $[5,6]$. Most phenological activities in the Himalayan species occur during the hot dry season before the onset of the monsoon [7]. Poor understanding prevails regarding role of drought in regulating tree species performance and distribution for Himalayan forests. However, existing data and indirect evidences suggest that distribution of trees is strongly dependent on drought [8, 9, and 10]. Osmotic potential can be lowered both passively and actively [11]. This lowering of osmotic potential due to increase in solute concentration (osmotic adjustment) has a significant role in contributing to drought

* Corresponding Author

E-mail: atewari69@gmail.com tolerance in several woody species [12]. Osmotic adjustment is a dehydration tolerance adaption/dehydration avoidance mechanism as it assists in water extraction from soil and also enhances root growth. Chir pine (Pinus roxburghii Sarg.) an economically valuable species is the dominant tree species between altitudes of 1300 and $2000 \mathrm{~m}$ in the Central Himalayan region. Chir pine forms pure stands generally but towards its upper limit mixes with oak (Quercus leucotrichophora A. camus) [13].

In the present study we have tried to assess the drought adaptation capacity of seedlings of Chir pine in relation to induced soil water stress and its impact on seedling growth and development.

\section{MATERIAL AND METHODS}

Cones of Chir pine were collected from 10 superior individuals in May end 2014 from one representative site of Pinus roxburghii located at $1710 \mathrm{~m}\left(29^{\prime} 22^{\circ} 0 \mathrm{~N}\right.$ lat. and $79^{\prime} 25^{\circ} \mathrm{OE}$ long.) in the Kumaun region of the Central Himalayas. Seeds were extracted from cones by drying them in sun. Seeds were sown singly in 140 polythene bags having soil from pure $P$. roxburghii forest stand collected previously. 
Measurements commenced from next year summer season (June $1^{\text {st }}$ week) when seedlings were $1 \mathrm{yr}$ old $7-10 \mathrm{~cm}$ in height and 4-6 $\mathrm{mm}$ in diameter. The seedlings were given 3 stress levels of 9 days interval and one lot of 20 seedling was kept as control (watered 3 times/week) and kept in a polyhouse. Before subjecting the seedlings to drought cycle 10 seedlings were harvested for initial biomass estimation and 20 seedlings were kept under each stress level. During the study period the mean minimum and mean maximum temperatures inside the polyhouse ranged between $8{ }^{\circ} \mathrm{C}$ and $36{ }^{\circ} \mathrm{C}$ and humidity between $63 \%$ and $91 \%$. The polyhouse temperatures were $4-7^{\circ} \mathrm{C}$ higher than outside temperatures.

Pre-dawn (5.30-6.30 AM) and Mid-day water potential was estimated using a pressure chamber (PMS 1000 make of PMS Instrument Company, Corvallis, USA [14]. Five replicates per stress level for each water potential measurement (pre-dawn and Mid-day) were used. The seedlings harvesting for Mid-day water potential estimation were placed in a plastic bag and used for P-V curve preparation. The bench drying method was followed for developing P-V curves for estimating components of water potential. Five individuals from each stress level were harvested for dry mass estimation and separated into needles, shoot and roots dried to constant weight at $60{ }^{\circ} \mathrm{C}$ [15]. Osmotic adjustment was considered to be the difference between the osmotic potential at zero and full turgor of seedlings kept at control and those given 27 days drought [16]. Soil moisture was determined on fresh weight basis by developing composite soil samples of five replicates, each of $10 \mathrm{~g}$ [17]. Data analysis was carried out in the Microsoft excel program. Analysis of variance (ANOVA) was used to observe the effect of moisture stress on seedling growth [18].

\section{RESULTS}

The 1 year old Chir pine seedlings were subjected to three drought cycles of 9,18 and 27 days in a polyhouse and monitored for water relation and growth parameters. The seedlings subjected to 27 day drought cycle had relatively low (-2.12 MPa) Pre-dawn water potential. No mortality was observed at 27 day of drought but total seedling dry mass was severely impact by increased drought.

The Pre-dawn and Mid-day water potential declined significantly with increasing stress. There existed a positive correlation between soil moisture and Pre-dawn water potential $\left(\mathrm{r}^{2}\right.$ $=0.963, \mathrm{p}<0.01)$. The Pre-dawn water potential declined significantly with increasing stress. The Pre- dawn water potential decline by 1.28 $\mathrm{MPa}$ in seedlings kept at control and these subjected to 27 days of drought cycle and mid day water potential by 1.1 MPa. No mortality was observed even in the seedlings subjected to high drought stress levels of 27 days. In Pinus roxburghii the durinal change in $(\psi)$ ranged from $0.61 \mathrm{MPa}$ (Control) to $0.18 \mathrm{MPa}$ in seedlings subjected to 27 days of drought. The pre dawn $(\psi)$ was significantly related to daily change in water potential $\left(r^{2}=0.807, p<0.05\right)$. Generally osmotic adjustment is calculated as the decline in osmotic potential over a period of drought here taken as the difference between control and 27 days drought cycle. The Osmotic Potential (OP) at full turgor and $\mathrm{OP}$ at zero turgor declined with increasing drought. The seedlings of $P$. roxburghii could osmotically adjust by $1.17 \mathrm{MPa}$ at full turgor and 2.0 MPa at zero turgor. This indicates the capacity of this species to resist drought. This adjustment may provide an ecophysiological advantage to the young seedlings of $P$. roxburghii to maintain photosynthesis activities even under high stress level (Table 1)

\subsection{Seedling growth}

Dry mass of seedling increased with increasing drought upto 9 days of drought interval and their by decreased with increasing drought. Positive relation existed between soil moisture and total seedling biomass $\left(\mathrm{r}^{2}=0.847, \mathrm{p}<0.01\right)$. The needle biomass had reduced by $82 \%$ percentage between control and 27 days drought cycle, root biomass by $77 \%$ and total biomass by $75 \%$ (Table 1). The root to shoot ratio was maximum in seedling subjected to 9 days of drought and then declined as the drought increased.

\section{DISCUSSION}

The controversy regarding the encroachment of Chir pine (P. roxburghii) into the banj oak (Q. leucotrichophora) zone has raged for the last few decades. We tried to assess the eco physiological reasons that make this species adaptive and invasive. By studying the water relation and growth parameters of Chir pine seedlings subjected to varying drought cycles. It is common to see that subsequent to disturbance $P$. roxburghii is expanding in transition zones at the cost of broad leafed species. Under natural condition the seedlings density at the site from where cones were collected was 1432 individuals/ha and $94.6 \%$ of the seeds collected from the cones germinated, $100 \%$ of the developed seedlings for the experiment survived.

Osmotic potential can be lowered by uptake, internal production or transfer of substances such as inorganic ions, amino acids and sugars or passively due to dehydration resulting in concentrating of the tissues solutes [11, 19]. Chir pine could osmotically adjust by close to $1.0 \mathrm{MPa}$ at full turgor and $2.0 \mathrm{MPa}$ at zero turgor. The capacity of Chir pine appears to be higher to osmotically adjust when compared with $P$. canariensis and $P$. pinaster (1.33 MPa and 0.54 MPa) [20].

The daily change in water potential had significant relation with Pre-dawn water potential values $\left(r^{2}=0.807, p<0.05\right)$, the daily change decline with increasing stress and it is evident that this species closes its stomata as stress increase to $-2.3 \mathrm{MPa}$. This could be a drought avoidance strategy of the species. Similar pattern has also been reported in Ziziphus rotundifolia Mill which tends to close its stomata at $-2.3 \mathrm{MPa}$ [2]. It has been reported that plant growth can be seriously impacted under water stress as nutrient movement is directly related to water availability in roots [21]. In seedling of $P$. roxburhii the dry mass increased only upto 9 days of drought cycle and there by decline with increasing stress. 
Table 1: Affect of drought cycle on water relation parameters and biomass of $P$. roxburghii seedlings.

\begin{tabular}{|c|c|c|c|c|}
\hline \multirow[t]{2}{*}{ Parameter } & \multicolumn{4}{|c|}{ Drought cycle } \\
\hline & Control & 9 Days & 18 Days & 27 Days \\
\hline Soil Moisture $(\%)$ & $38.0 \pm 0.1$ & $32.0 \pm 0.1$ & $25.0 \pm 0.9$ & $11.0 \pm 0.0$ \\
\hline Relative Water Content at zero turgor (\%) & $92.0 \pm 0.2$ & $87.0 \pm 0.01$ & $63.5 \pm 0.06$ & $53.0 \pm 0.01$ \\
\hline Predawn Water Potential (MPa) & $-0.59 \pm 0.7$ & $-1.1 \pm 0.4$ & $-1.58 \pm 0.6$ & $-2.12 \pm 0.4$ \\
\hline Mid Day Water potential(MPa) & $-1.2 \pm 0.0$ & $-1.4 \pm 0.04$ & $-1.78 \pm 0.2$ & $-2.3 \pm 0.1$ \\
\hline Osmotic Potential at full turgor (MPa) & $-0.81 \pm 0.2$ & $-0.90 \pm 0.3$ & $-1.56 \pm 0.4$ & $-1.98 \pm 0.01$ \\
\hline Osmotic Potential at zero turgor (MPa) & $-1.27 \pm 0.6$ & $-2.32 \pm 0.5$ & $-2.50 \pm 0.8$ & $-3.27 \pm 0.5$ \\
\hline Root : Shoot ratio (by length) & $1.61 \pm 0.3$ & $1.61 \pm 0.5$ & $1.34 \pm 0.1$ & $1.50 \pm 0.0$ \\
\hline Total Biomass (g seedling ${ }^{-1}$ ) & $4.59 \pm 0.52$ & $5.34 \pm 0.64$ & $2.639 \pm 0.12$ & $1.299 \pm 0.45$ \\
\hline
\end{tabular}

\section{CONCLUSION}

For normal growth maintenance a relatively high water content and turgor pressure is essential. As water stress is common in several environments, many tree species have developed varied mechanisms to cope with drought. Some species tolerate water stress through osmotic adjustment or the accumulation of osmotic protective substances. The capacity of this species to adjust osmotically by $1.17 \mathrm{MPa}$ at full turgor and $2.0 \mathrm{MPa}$ at zero turgor appears to be the major drought tolerance mechanism of $P$. roxburghii seedlings. The capacity of Chir pine to invade and develop on drought prone areas may be related to its ability to accomplish high osmotic adjustment and appears to be a primary factor contributing to its drought tolerance capacity for invasion and mass of natural regeneration in this species.

\section{Financial support and sponsorship: Nil.}

Conflict of Interests: There are no conflicts of interest.

\section{REFERENCES}

1. Worbes M, Blanchart S, Fichtler E. Relations between water balance, wood traits and phenological behavior of tree species from a tropical dry forest in Costa Rica multi factorial study. Tree Physiology. 2013; 33: 527-53.

2. Arndt S.K, Clifford S.C, Wanek W, Jones H.G, Popp M. Physiological and morphological adaptation of the fruit tree Ziziphus rotundifolia in response to progressive drought stress. Tree Physiology. 2001; 21:705-715.

3. Craine J.M, Engelbrecht B.M.J, Lusk C.H, McDowell N.G, Poorter $\mathrm{H}$. Resource limitation tolerance and the future of ecological plant classification. Front Plant Science. 2012; 3:246,

4. Zobel D.B, Singh S.P. Himalayan Forests and ecological generalization. BioScience. 1997; 47: 35-745.

5. Ralhan P.K, Khanna R.K, Singh S.P, Singh J.S. Phenological characteristics of the tree layer of Kumaun Himalayan forests. Vegetatio. 1985; 60: 91-101.

6. Ralhan P.K, Khanna R.K, Singh S.P. Dynamics of nutrients and leaf mass in central Himalayan trees and shrubs. Ecology. 1987; 68:1974-1983.

7. Singh S.P, Tewari A, Singh S.K, Pathak G.C. Significance of phenologically asynchronous populations of the central Himalayan oaks in drought adaptation. Current Science. 2000; 79(3):353-357

8. Zobel D.B, Singh S.P. Tree water relations along the vegetational gradient in the Himalayas. Current Science. 1995; 68: 742-745.

9. Poudyal K, Jha P.K., Zobel D.B., Thapa C.B. Patterns of leaf conductance and water potential of five Himalayan tree species. Tree Physiology. 2004; 24: 689-699.
10. Shrestha B.B, Jha P.K, Zobel D.B. Water relations and phenology of Pinus roxburghii Sarg. in the Churia hills, central Nepal. International Journal of Ecology \& Environmental Science. 2006a; 32 (2):183-192.

11. Teskey R.O, Hinckley T.M. Moisture effects of water stress on trees. In: Henessery TC, Dougherty PM, Kossuth SV, Johnson JD, editors. Stress physiology and forest productivity, Netherlands : M. Nijhoff E-Publishing, Dordrecht; 1986, p.9-33.

12. Vivin P, J.M. Guehl, Clément A, Aussenac G. The effects of elevated $\mathrm{CO} 2$ and water stress on whole plant $\mathrm{CO} 2$ exchange, carbon allocation, and osmoregulation in oak seedlings. Ann. Sci. For. 1996; 53: 447-459.

13. Pant H, Tewari A. Carbon Sequestration in Chir-Pine (Pinus roxburghii Sarg.) Forests under various disturbance levels in Kumaun Central Himalaya. Journal Forestry Research. 2014; 25 (2): 401-405.

14. Pinto C. A, David J. S, Cochard H, Caldeira M. C, Henriques M. O, Quilho T, Paco T. A, Pereira J. S, David T. S. Drought-induced embolism in current-year shoots of two Mediterranean evergreen oaks. Forest Ecology and Management. 2012; 285:1-10.

15. Bargali $\mathrm{K}$, Tewari A. Growth and water relation parameters in drought-stressed Coriaria nepalensis seedlings. Journal of Arid Environment. 2004; 58: 505-512.

16. Edwards D.R, Dixon M.A. Mechanisms of drought response in Thuja occidentalis L.I: water stress conditioning and osmotic adjustment. Tree Physiology. 1995; 15:121-127.

17. Sharma N, Kumar A, Ram J, Tewari A. Water relation study on seedlings of Quercus leucotrichophora in a greenhouse. Ecology Environment \& Conversation. 2001; 7(3):301-305.

18. Snedecor G.W, Cochran W.G. Statistical methods, Oxford and IBH Publishing Co., New Delhi; 1967.

19. Mathson W.J, R.A Haack. The role of drought in outbreaks of plant eating insects. Bioscience. 1987; 37: 110-118.

20. Lopez R, Aranda I, Gil L. Osmotic adjustment is a significant mechanism of drought resistance in Pinus pinaster and Pinus canariensis. Forest Systems. 2009; 18 (2): 159- 166.

21. Bisht K. Growth of Quercus leucotrichophora A. camus and Pinus roxburghii Sarg. seedlings in relation to nutrient and water. Proceedings of Indian National Science Academy. 1993; 59: 71-78.

\section{How to cite this article:}

Tewari A, Mittal A. Effect of Artificially Induced Drought Stress on Seedlings of Pinus roxburghii Sarg. J App Biol Biotech. 2017; 5 (01): 076-078. DOI: 10.7324/JABB.2017.50113 